\title{
THE ROLE OF RELIGIOUS RITUAL IN SOCIAL CAPITAL FORMATION FOR POVERTY ALLEVIATION AND SOCIAL DEVELOPMENT: THEORETICAL AND METHODOLOGICAL POINTS OF DEPARTURE OF A SOUTH AFRICAN EXPLORATION
}

\author{
CAS WEPENER, IGNATIUS SWART, GERRIE TER HAAR, MARCEL BARNARD ${ }^{1}$
}

\begin{abstract}
The article is a presentation of a South African research project in which researchers in the fields of ritual-liturgical studies and social development are collaborating to explore the role of religious ritual in the kinds of social capital formation that have a direct significance and implication for alleviating poverty and promoting social development at grassroots level. Focusing on Christian congregations in poor socio-economic contexts in the Western Cape and KwaZulu-Natal, the aim of the research is to understand social capital formation through the lens of religious ritual. The research project builds on the hypothesis that social capital has a role to play in the related goals of poverty alleviation and social development, something which it seeks to conceptualise and explore in greater detail. Within this framework the discussion explores and contextualises the conceptual link between social capital and the practice of religious ritual in present-day South African society by drawing on existing research and theoretical debates, both nationally and internationally. This enables the authors to present some additional notes on the key theoretical, conceptual and methodological points of departure of the undertaken project. These are followed by a number of concluding observations about the modes of investigation and action steps through which the research topic is currently being further developed.
\end{abstract}

\section{Introduction}

In 2008 a project funded by the National Research Foundation (NRF) was started in the Western Cape and KwaZulu-Natal provinces of South Africa to explore the role of religious ritual in the kinds of social capital formation that are relevant to the related objectives of alleviating poverty and promoting social development at grassroots level. ${ }^{2}$ With this aim in mind, the project seeks to understand the role of religion in social capital formation by examining it through the lens of ritual.

\footnotetext{
${ }^{1}$ Cas Wepener is a part-time lecturer in Liturgical Studies and a Research Associate at the Department of Practical Theology, Faculty of Theology, University of the Free State and leads the research project from Stellenbosch University discussed in this article (cwepener@kingsley.co.za); Ignatius Swart is Executive Director: Teaching and Research at the Huguenot College, Wellington (iswart@sun.ac.za); Gerrie ter Haar is Professor of Religion and Development at the Institute of Social Studies in The Hague (terhaar@iss.nl); Marcel Barnard is Professor of Liturgical Studies at Protestant Theological University, Utrecht, and at VU University, Amsterdam (mbarnard@pthu.nl).

${ }^{2}$ Based at the University of Stellenbosch, the project runs from 2008-2011 under NRF Grant number 65620 and is entitled, 'Exploring the role of religious ritual in social capital formation for poverty alleviation and social development in poor South African communities'. Any opinion, findings and conclusions or recommendations expressed in this material are those of the authors and therefore the NRF does not accept any liability in regard thereto.
} 
In recent years a number of research projects have focused on the role of religious communities with regard to social service delivery. ${ }^{3}$ Very little, if any, research has focused specifically on the contribution of religious communities to value formation and the role of phenomena such as rituals in this. We believe that the research endeavours described in this article make the non-material contribution of religion toward poverty alleviation and social development intelligible and help explain the relationship between religious ritual and social capital formation.

During the past decade some remarkable shifts have taken place in South African public life, which have had significant effects for policy making. One important result of this changed policy environment is that an actor such as the broad religious sector has lost the central position that it enjoyed in the political struggle against 'apartheid' and has, on many accounts, been delegated to the margins of what has become a preoccupation with the market and other 'development' concerns in the new South Africa. Yet such a perspective does not do justice to the continuing importance of religion in South African communities. Although a substantial amount of research has been done on the role of faith-based organisations (FBOs) in social service delivery in South African society, ${ }^{4}$ little academic research has been undertaken to explore the specific potential of a dimension so inherent to religious communities as ritual in the generation of social capital.

With this scope for innovative research in mind, the following research question has been formulated: 'How and to what extent does religious ritual contribute to the formation of the kinds of social capital that assists or could assist in alleviating poverty and promoting social development in South African communities?' In the sections that follow we explain the contextual background and rationale for exploring this particular question, as well as how we are attempting to answer the question. In particular, through this explanation our aim is to present more detailed evidence of how we have started to conceptualise the link between our key focus areas of social capital formation and the practice of religious ritual within the specific context of South African society. After also giving a brief explanation of the choice of the specific congregations and communities involved in our research, the key theoretical, conceptual and methodological points of departure of our undertaken research are discussed. This is followed in conclusion by a number of observations about the modes of investigation and action steps through which our research topic is currently being further developed. Finally, an extensive bibliography is presented to indicate the type of sources that appear to be helpful in bringing together the two main disciplinary fields in which the project is rooted: ritual-liturgical studies and religion and development studies, with a specific focus on the issue of social development.

\section{Social capital and religious ritual ${ }^{5}$ in impoverished South African communities}

Poverty is one of the social problems plaguing South Africa and has also been linked in a recent contribution from the project group to the structural condition of social exclusion in the country. ${ }^{6}$

\footnotetext{
${ }^{3}$ Cf. in this regard Swart et al., Religion and Social Development in Post-Apartheid South Africa: Perspectives for Critical Engagement (Stellenbosch: SUN Press, 2010 forthcoming).

${ }^{4}$ Such a research focus, for instance, characterised the NRF-funded project on 'Faith-Based Organisations, Social Capital and Development' (2004-2006) that preceded the current project and that has led to the forthcoming book publication, Swart et al., Religion and Social Development in Post-Apartheid South Africa; for a more detailed overview of the project results, see I. Swart, 'Meeting the Challenge of Poverty and Exclusion: The Emerging Field of Development Research in South African Practical Theology,' International Journal of Practical Theology 12, no. 1 (2008): 104-149.

${ }^{5}$ In using the broad denominator 'religious ritual' we include Christian worship as performed mainly on a Sunday in churches.
} 
Yet, as a recent public debate on the domination of market economic values in postapartheid South African society has shown, a narrow-minded economic and materialistic approach to the issue of poverty may be regarded as very much a part of the general mindset in this society. ${ }^{7}$ Yet on the international stage social scientists and even an institution such as the World Bank are today highlighting the fact that such a narrow-minded emphasis should not be seen as a South African problem only. In particular, in their new attempt to adopt a broader approach, these scholars and the Bank are pointing to the fact that a general neglect of the role that 'social capital' and 'social capital formation' has to play may well lie at the core of the current failure to address the problem of poverty effectively. ${ }^{8}$

Returning to a more specific South African perspective we would like to refer at this point to a recent article by Cilliers and Wepener in which these two authors advance the thesis that the manifestation of poverty could also be defined as, among other things, the 'absence of social capital'. These two authors argue that poverty may be defined as the inverse of the presence of social capital, which implies that people and communities belonging to the rich stratum of society may also be defined as being poor. Based on this presumption Cilliers and Wepener define poverty as 'a state of affairs where the absence of material resources, the denied space for trust and identity forming, as well as the loss of civil skills impact negatively on one another, in a seemingly unstoppable and negatively escalating spiral. ${ }^{9}$ Such a definition of poverty implies that the generation of social capital could potentially have positive impacts on poverty alleviation. In the light of this definition of poverty as the absence of social capital, the authors then explore the role of rituals in the generation of social capital. $^{10}$

Clearly, then, Cilliers and Wepener's argument on the relation between poverty and social capital relates well to another South African scholarly contribution, by I. Swart, that has pointed to a new interest among public policy-makers in South Africa to promote a strategy of social capital formation in order to address issues of poverty and social exclusion in South African communities. Focusing in particular on the 'Social Capital Formation Document' that was issued by the Western Cape Provincial Government's Department of Social Development in 2005, Swart concluded that on the basis of this document a strategy of social capital formation had shifted to the forefront of 'public sector intervention to meet the challenge of social exclusion and provide disadvantaged communities with access to networks and socioeconomic opportunities. ${ }^{11}$ However, this observation of a new interest in social capital also led him to make an important critical comment about the limited perspective on agency in the document. In particular, this shortcoming related to the way in which the compilers of the

\footnotetext{
${ }^{6}$ See Swart, 'Meeting the Challenge of Poverty and Social Exclusion'; cf. also the supplement of the South African theological journal Nederduitse Gereformeerde Teologiese Tydskrif 45, no. 2 (2004), which was entirely devoted to the issue of poverty and to which a number of participants in the current project contributed.

7 See I. Swart, 'Market Economic Development, Local Economic Experience and the Christian Movement Towards Alternatives in a South African City Region,' in From Our Side: Emerging Perspectives on Development and Ethics (eds. S. de Gruchy, N. Koopman and S. Strijbos; Amsterdam: Rozenberg, 2008).

${ }^{8}$ See P. Francis, 'Social Capital, Civil Society and Social Exclusion,' in Development Theory and Practice: Critical Perspectives (eds. U. Kothari and M. Minogue; New York: Palgrave, 2002), 71, who refers to the identification in current development debates of social capital as the 'missing dimension' in social development programmes and projects; see also the World Bank on the topic at http://go.worldbank.org/C0QTRW4QF0 (accessed 01/09/09) where the Bank states in an overview article that '(s)ocial capital, when enhanced in a positive manner, can improve project effectiveness and sustainability by building the community's capacity to work together to address their common needs, fostering greater inclusion and cohesion, and increasing transparency and accountability.'

${ }^{9}$ J. Cilliers and C. Wepener, 'Ritual and the Generation of Social Capital in Contexts of Poverty: A South African Exploration,’ International Journal of Practical Theology 11, no. 1 (2007): 44.

${ }^{10}$ Cf. Cilliers and Wepener, 'Ritual and the Generation of Social Capital,' 44-55.

${ }^{11}$ I. Swart, 'Churches as a Stock of Social Capital for Promoting Social Capital in Western Cape Communities,' Journal of Religion in Africa 36, no. 3-4 (2006): 347.
} 
document attached great significance to the role of traditional values in the formation of social capital without adopting a more comprehensive view on the social actors who would be responsible for the revival of such traditional values. In this sense this perspective on agency became an argument that also had to pay attention to the foundational role of religious actors in reviving the values that were called for. To quote here at some length from the argument put forward in Swart's article:

By appearing in essence ... to be a strategic document in the first place for a specific governmental actor, but secondly also for social workers and social development workers, one is left with the question as to what role there could be for other actors in the envisaged social capital formation strategy. Indeed, this question becomes particularly relevant when one, for instance, considers the strategic challenge captured by the social capital formation notions of 'relationships' and 'values' in the document. Whilst one can fully concur with the document that there is a fundamental enabling role for government to play in the social capital formation process, one in which social workers and social development workers also have a very important facilitating role to play, it at the same time also seems very doubtful that these actors could be primarily responsible for mediating the deeper processes of relational and value formation that are asked for.

This article proceeds from the thesis that a process of social capital formation can only be successfully realised through the collective participation of all institutions and actors in society. In aiming to contribute to this perspective specifically from the point of view of the faith-based sector, the approach is furthermore not one in which certain aspects of a social capital formation strategy are viewed as providing the sole mandate for particular actors, but rather one in which the various aspects or dimensions are seen as being interrelated and the mutual responsibility of the collectivity of social actors. Applied to the Christian churches, whilst an argument about their participation in a social capital formation strategy will naturally entail a consideration of their contribution or potential contribution to the relational and value foundations of the kind of social capital formation strategy asked for above, this can not be done in isolation from the other dimensions that we have identified. In particular, in terms of our constructed framework of analysis, we are here also interested in developing a perspective on the nature and extent of local churches' own service delivery and development activities, the kind of connections that are fostered through such activities, and the levels of trust towards which they (local churches) might be contributing to as a basis for meaningful social capital formation and development activity. ${ }^{12}$

It is at this point that a more pertinent statement can be made about the aim and scope of our current project. Whilst drawing directly upon the above-mentioned conceptual and strategic linkages between 'poverty', 'social exclusion', 'social capital', 'social development' and 'religious agency', project participants are seeking to explore specifically the role of religion and religious ritual in social capital formation. In this regard the current project seeks to move beyond the notion of religious communities as being mainly providers of spaces for service delivery, or their material contributions to social development, although these matters are very important indeed. More than anything else, the participants in our project are interested in the role of the non-material and the uniquely religious aspects of religion in the generation of social capital, which makes a contribution to social development and ultimately to the alleviation of poverty. It is thus an exploration of how religious communities are making a contribution towards social capital formation by means of their core religious activities such as rituals. ${ }^{13}$

However, we want to conclude with other commentators that the non-material role of religion in development is mostly underestimated and not well understood. ${ }^{14}$ So, for example,

\footnotetext{
${ }^{12}$ Swart, 'Churches as a Stock of Social Capital,' 353-354.

${ }^{13}$ With regards to the importance of religion in development and especially also the non-material contribution of religion in development, cf. the conference report Transforming Development: Exploring Approaches to Development from Religious Perspectives (Utrecht: Knowledge Centre Religion and Development, 2007). This document is also available at www.religie-en-ontwikkeling.nl; see also G. ter Haar and S. Ellis, 'The Role of Religion in Development: Towards a New Relationship between the European Union and Africa,' The European Journal of Development Research 18, no. 3 (2006): 351-67.

${ }^{14}$ Cf. Ter Haar and Ellis, ‘The Role of Religion in Development,' 351-367.
} 
the Global Civil Society Report of 2004/5 states that 'there is no way we can understand the logic, strategies and dynamics of civil society anywhere in the Third World, unless we bring the transcendental dimension back into our analysis. ${ }^{15}$ The role of religious communities in social capital formation is well researched with ample literature on the topic, ${ }^{16}$ and most researchers emphasise their important role in this respect. Regarding the uniquely religious contributions of religious communities in social capital formation, much research is still needed, however. In view of the lacuna in understanding of the specific role of religion and religious ritual in development, the current project strives to make a contribution towards a better understanding of it. Given the South African religious landscape regarding people's participation in religious rituals and worship, the need for, and appropriateness of, such a research project in South Africa is evident, especially given the project's specific focus on religious ritual.

With the above-mentioned South African and international social context in mind, along with the way in which some policy documents address the predicament of poverty and social exclusion, and especially given the project's interest in the role of religious ritual in such a context, the South African religious landscape should be outlined in order to situate our research within its specific setting. According to the census statistics of $2001,79.8 \%$ of the South African population belong to the Christian religion, and almost $4 \%$ to other religions. With regards to Christianity, this is a rise of almost $5 \%$ from the previous (1996) census. ${ }^{17}$ The biggest repertoire of religious rituals is found in religious services, such as the weekly worship service of churches. According to statistics presented by the Community Agency for Social Enquiry (CASE), as many as 91\% of persons between the ages of 18 and 35 indicated that they attend worship services, ${ }^{18}$ and according to the World Values Survey (1999-2002), the most conservative figure for persons attending religious services in South Africa at least once a month is $71.77 \%$. Along with these statistics on religion and religious worship services, national social surveys conducted over recent years by institutions such as the Human Sciences Research Council (HSRC) and Institute for Justice and Reconciliation (IJR) have provided evidence of the high level of public trust that churches and religious institutions in general enjoy in South Africa. Indeed, these surveys as well as other scholarly research have shown that in present-day South African society churches and other religious institutions are not only very well represented in terms of membership and demographic spread; ${ }^{19}$ they are also by far outscoring other institutions, notably government but also institutions of civil society and business, in terms of public confidence and credibility. ${ }^{20}$

\footnotetext{
${ }^{15}$ H. Anheier et al., Global Civil Society 2004/5 (London: Sage, 2004$), 45$.

${ }^{16}$ Cf., among others, N. T. Ammerman, Congregation \& Community (New Brunswick/ New Jersey/ London: Rutgers University Press, 1997) and R. Putnam, 'Bowling Alone: America's Declining Social Capital,' Journal of Democracy 6, no. 1 (1995): 65-78.

${ }^{17}$ H. J. Hendriks, 'Census 2001: Religion in South Africa with Denominational Trends 1911-2001,' in South African Christian Handbook 2005-2006 (Cape Town: Christian Network, 2005), 29, 39-40, 83.

${ }^{18}$ Cf. N. Koopman, 'Publieke Teologie in Suid-Afrika Vandag: Die Verhaal van die Beyers Naudé Sentrum vir Publieke Teologie.' Ongepubliseerde referaat gelewer by die Universiteit van Stellenbosch Dosente Forum reeks, 18 Mei 2005; C. J. Wepener, 'Participation and Power: Opportunities for Method and Theory in Liturgical Research from a Changing (Dutch Reformed) South African Liturgical Landscape,' Jaarboek voor Liturgieonderzoek 22 (2006): 50-51.

${ }^{19}$ In addition to the references in the previous two footnotes, see H. J. Hendriks and J. C. Erasmus, 'Religious Affiliation in South Africa Early in the New Millennium: Markinor's World Values Survey,' Journal of Theology for Southern Africa 117 (November 2003): 80-96; H. J. Hendriks, J. C. Erasmus and G. G. Mans, 'Congregations as Providers of Social Service and HIV/AIDS Care,' Dutch Reformed Theological Journal 45, no. 2 (2004 Supplementum): 380-402.

${ }^{20}$ Human Sciences Research Council (HSRC), 'Broken Trust, a Wake-up Call for Major Institutions,' Media briefs 2000. Accessed online 18 February 2008 at http://www.hsrc.ac.za/Media_Release-140.phtml; Institute for Justice and Reconciliation (IJR), 'South Africa: Trust in Institutions Takes a Dive,' Business Day, 22 January 2008. Accessed online 18 February 2008 at http://allafrica.com/stories/200801220202.html.
} 
The above-mentioned statistics and facts suggest a potential impact of religious communities and their rituals on South African society that needs further exploration. This especially concerns the influence of rituals on matters such as the formation of social capital. The link between ritual and (the sustenance and reproduction of) the social order is well known. ${ }^{21}$ Some research has been conducted showing the link between ritual and value formation, ${ }^{22}$ the link between ritual and identity formation, ${ }^{23}$ as well as the link between ritual and social capital formation. ${ }^{24}$ But there remains a real need for a larger-scale research project investigating the link between ritual and the social order, especially as pertaining to social capital within the current South African context.

In order to focus the research, the religious communities involved are Christian churches. Of the 79.8\% Christians in South Africa, results from the 2001 national census indicated that $31.8 \%$ belong to the so-called mainline churches and $32.6 \%$ to the so-called African Independent Churches (AICs), which constitute the biggest Christian groups in South Africa. ${ }^{25}$ These two groups also constitute the main focus of the research: of the four religious communities whose rituals are scrutinised, two come from the mainline churches and two from the African Independent Churches. One mainline church and one AIC are situated and in KwaZulu-Natal, and another mainline church and AIC congregation in the Western Cape.

After a pre-proposal workshop with participants from the provinces involved, a preliminary review of statistics, some meetings with academics engaged in AIC research and/or teaching AIC leaders, further negotiations with participating students and field workers as well as a visit of the project leader to the local communities, the towns of Kokstad (KwaZulu-Natal) and Worcester (Western Cape) were identified as research sites. With assistance of the URDR (Unit for Religion and Development Research) at Stellenbosch University these two towns are currently being mapped in some detail. Both project leader ${ }^{26}$ and project participants have visited the local communities to meet with church leaders and to get informed consent for the research. ${ }^{27}$

\section{Strategic significance}

The above outline of the background and motivation for the research can further be related to recent debates on the relation between religion and development and the ongoing discourse on collaboration between religious actors and the state to promote development. In the South African context both Koegelenberg and Swart have discussed the way in which government values the positive role that religious communities can play with regard to social

\footnotetext{
${ }^{21}$ Cf. the work of sociologists and anthropologists such as Emile Durkheim, Cliffords Geertz, Alfred RadcliffeBrown and Victor Turner in this regard.

${ }^{22}$ Cf. G. Lukken, Rituals in Abundance: Critical Reflections on the Place, Form and Identity of Christian Ritual in Our Culture. Liturgia Condenda 17 (Leuven/ Dudley, MA: Peeters, 2005), 54-73; K. Pecklers, Worship. New Century Theology (London/ New York: Continuum, 2003) and D. J. Smit, 'Lex Orandi, Lex Credendi, Lex (Con)vivendi: Oriënterende Inleiding tot Liturgie en Etiek,’ Nederduits Gereformeerde Teologiese Tydskrif 45, no. 3 \& 4 (2004): 887-907.

${ }^{23}$ Cf. H. J. C. Pieterse, 'Die Rol van Rituele en Simbole in die Identiteitsvorming van 'n Geloofsgemeenskap 'n Gereformeerde Perspektief,' Skrif en Kerk 19, no. 2 (1998): 342-347; C. J. Wepener and J. C. Pauw, 'Terug na die Toekoms - oor die Samehang tussen Rituele, Tyd en Identiteit,' Scriptura 85, no. 1 (2004): 110-122; C. J. Wepener, 'Liturgy on the Edge of Tradition,' Practical Theology in South Africa 23, no. 2 (2008): 313-335.

${ }^{24}$ Cilliers and Wepener, 'Ritual and the Generation of Social Capital'.

${ }^{25}$ Hendriks, 'Census 2001,' 28.

${ }^{26}$ Cas Wepener visited the local communities in KwaZulu-Natal several times in 2008 and met with local church leaders, field workers and students there.

27 At this stage we are keeping these congregations confidential, because of the often very personal and sometimes even potentially sensitive nature of both the performance of rituals and the subject of poverty.
} 
development, arguing for formal cooperation between the state and religious communities. ${ }^{28}$ However, in order to enhance the quality of such cooperation, research of the kind described in this article is needed, so that policy makers can utilise well-researched information on the role of religious communities in promoting social development through social capital formation. Hence firstly the project's emphasis on the importance of social capital and value formation for government, on the one hand, and the role of ritual with regard to value formation and social capital formation, on the other. And secondly the strategic aim of the project to bring our understanding of the role of religious ritual in social capital formation to the attention of policy makers in South Africa and abroad.

We hinted already at the fact that the debate on the role of religion in development is not limited to the reality of South Africa. In the Netherlands, for example, in 2006 the Knowledge Centre for Religion and Development (KCRD) was founded to explore the role of religion in the development process. This is a joint initiative by several Dutch faith-based organisations ${ }^{29}$ that was born out of a concern about the general lack of knowledge about the role of religion in people's lives and the consequences of this for the practice of development cooperation. The Knowledge Centre seeks to put into practice the insight that religion is an important factor for sustainable development and for building international cooperation and civil society by stimulating broad reflection on the meaning of religion for sustainable development and by developing methodologies that allow for a greater focus on religion in development policies. ${ }^{30}$

Yet, when returning to the South African context we note that at present the debate on 'social capital formation is shifting to the centre of social development policy discourse'. ${ }^{31} \mathrm{~A}$ research project like the present one therefore enhances reflection on the nature of partnerships between the state and religious communities. In his strategic vision entitled 'Mobilising for a Caring Society', Dr. Zola Skweyiya, Minister for Social Development, stated that 'we can only succeed to eradicate poverty in our country if we can build effective partnerships between the state, the religious sector and other institutions of civil society'. He added that:

Apart from the large networks available to churches (and other religious networks), the resources they have at their disposal, we also know they can play a crucial role in the formation of values and the moral fibre of our society. As Department of Social Development we have launched a national campaign to create 'a caring society' in South Africa. How can we succeed with this effort without the support of our religious communities - which are known for their networks reaching into even rural parts of South Africa? ${ }^{32}$

There is a large body of research and hypotheses on the role of religious communities in social capital development, ${ }^{33}$ along with some preliminary research articles on the function of

\footnotetext{
${ }^{28}$ Cf. R. A. Koegelenberg, 'Social Development Partnerships between Religious Communities and the State: Perspectives from the National Religious Association for Social Development,' Journal of Theology for Southern Africa 110 (July) (2001): 97-109; Swart, 'Churches as a Stock of Social Capital.'

29 These include Cordaid, a development organisation with a Catholic tradition; ICCO, an inter-church organisation for development; the Islamic University Rotterdam (IUR), an organisation for Islamic education; Oikos, an ecumenical organisation which supports activities in the Netherlands; and Seva Network Foundation, an international organisation for development co-operation inspired by Hindu values. See www.religion-anddevelopment.nl.

30 Cf. www.religie-en-ontwikkeling.nl or www.religion-and-development.nl, especially the KCRD report. Transforming Development.

${ }^{31}$ Swart, 'Churches as a Stock of Social Capital,' 347.

32 Quoted by Koegelenberg, 'Social Development Partnerships,' 108.

${ }^{33}$ E.g. R. K. Brown and R. E. Brown, 'Faith and Works: Church-Based Social Capital Resources and African American Political Activism,' Social Forces 82, no. 2 (2003): 617-641; L. Louw and R. A. Koegelenberg 'Building a New South Africa: The Building of a Caring, Democratic and Equitable Society through Partnerships between the State and the National Religious Leader's Forum (NRLF).' Position paper prepared for the NRLF meeting with former President Thabo Mbeki, 29-30 April 2003. 'A Perspective from the National Religious Association for Social Development (NRASD).' Accessed online 18 February 2008 at
} 
rituals within this whole. ${ }^{34}$ However, what is still needed is focused qualitative research that works in an inductive and participatory fashion from a grassroots level within an action paradigm. This is confirmed by the 'Social Capital Formation Document' referred to in the previous section, which states that ' $(\mathrm{t})$ here is a need for a scientific base of the stock of social capital in the Province of the Western Cape in order to guide the types of interventions required to facilitate the formation of further social capital' ${ }^{35}$ In response to this quest, our current research project strives to contribute to this aim, because it focuses on specific churches in the Western Cape and KwaZulu-Natal, analysing the functioning of their ritual systems and comparing this with certain social development concepts. More and more researchers have concluded that religious communities' biggest contribution towards social development lies on the level of value formation. As an important carrier and communicator of these values, religious rituals have very rarely been the explicit focus of a research project that investigates the connection between these phenomena and social development. There is a great demand in this area for research concerning religious communities and their possible role in social development; the project responds to this demand by focusing on one of the core activities of religious communities, in this case worship, rather than on their material resources and infrastructure. There is thus a demand for understanding, because it is becoming increasingly clear that there is a link between religion and social capital, but there is uncertainty about what exactly that link is.

\section{Theoretical and conceptual framework}

In this section we want to explain in somewhat greater detail the key theoretical concepts that guide our research.

\section{Development}

In recent years there has been a notable shift from an almost exclusively economic approach in development towards an approach that incorporates other aspects, notably the spiritual and social dimensions in development. ${ }^{36}$ To religious believers this broader approach often implies, instead of a mere emphasis on results, a greater attention to the 'road' to development, to right relationships, collaboration and personal and social transformation. Accordingly it includes attention to the importance of 'community' and the role of communities, compared to an approach that focuses exclusively on the role of the individual. In the same vein, cooperation is identified and prioritised above competition, which is an inherent feature of a predominantly economic paradigm. ${ }^{37}$ Others have commented in this regard that ' $(w)$ hat is needed is a wholesale reconsideration of the values which drive the

\footnotetext{
http://www.sarpn.org.za/documents/d0000557/P506_Social_Development.pdf; $\quad$ Koegelenberg, 'Social Development Partnerships;' I. Swart, 'Mobilising Faith-based Organisations for Social Development through a Participatory Action Research (PAR) Process,’ Social Work/Maatskaplike Werk 41, no. 4 (2005): 323-336; Swart, 'Churches as a Stock of Social Capital.'

${ }^{34}$ Cf. C. J. Wepener and J. H. Cilliers, 'Research on Liturgy and the Generation of Social Capital in Contexts of Poverty: A South African Exploration,' in Religion and Social Development in Post-Apartheid South Africa: Perspectives for Critical Engagement (eds. I. Swart, H. Rocher, J. Erasmus and S. Green; Stellenbosch: SUN Press, 2010 forthcoming).

${ }^{35}$ Department of Social Services and Poverty Alleviation, Social Capital Formation Document. Prepared for Cabinet Legkotla, 9-10 February 2005, 20.

${ }^{36}$ See K. Marshall, 'Development and Religion: A Different Lens on Development Debates,' Peabody Journal of Education 76, no. 3/4 (2001): 339-75; K. Marshall and L. Keough, Mind, Heart and Soul in the Fight against Poverty (Washington: World Bank, 2004); W. Tyndale, 'Faith and Economics in 'Development': A Bridge Across the Chasm?' Development in Practice 10, no. 1 (2000): 9-18; K. A. Ver Beek, 'Spirituality: A Development Taboo,' Development in Practice 10, no. 1 (2000): 31-43.

${ }^{37}$ In addition to the references in the previous footnote, see also K. Verhagen, 'Organized Religion: The Forgotten Dimension,' in Beyond Prince and Merchant: Citizen Participation and the Rise of Civil Society (ed. J. Burbidge; New York: Pact Publications, 1997), 263-273.
} 
present economic and financial systems which dominate our lives. ${ }^{38}$ The same author notes that there is an intimate connection between the reduction of reality to quantitative, measurable data on the one hand and the replacement of virtues by their opposites, vices, on the other. ${ }^{39}$ The belief that for effective development a holistic or integral approach is required is also aptly reflected in some recent World Bank publications, referring to the need for mind, heart and soul to work together. ${ }^{40}$ This latter meaning and the others mentioned above indeed relates closely to our concept of social development in the project, which we want to understand in the broadest sense as modes of human interaction and activities of empowerment that direct individuals and communities and give meaning and purpose to their lives.

\section{Social capital}

Social capital can be defined in numerous ways. Even a brief overview of literature in this regard reveals a rich tapestry of nuances and perspectives. Social capital has been defined as (i) the degree to which a community or society collaborates through mechanisms such as networks, shared trust, norms and values to achieve mutual benefits; (ii) the value of social networks - associated with trust, reciprocity, information and cooperation - that people can draw on to solve problems; (iii) the attitude, spirit and willingness of people to engage in collective, civic activities; (iv) skills and infrastructure that aid in social progress; (v) a composite measure that reflects both the breadth and depth of civic community as well as the public's participation in political life; and (vi) the degree of social cohesion which exists in communities, and so on. ${ }^{41}$ Although the concept of social capital is at present rather woolly, the above-mentioned qualities of the concept show that it could be helpful in challenging a narrow-minded view of both poverty and development, as described above. The literature on the topic of social capital with regard to religious communities is equally rich, ${ }^{42}$ and is utilised in our research.

\section{Ritual}

Ritual is a much discussed concept. ${ }^{43}$ In our project the concept of ritual is understood and used in a broad sense. Mainly, ritual is seen as language - i.e. speech and body language, as

\footnotetext{
${ }^{38}$ W. Tyndale, ‘Towards Sustainable Development: A Shift in Values', Commentary International Movement for a Just World 1, no. 8 (August 2001): 3.

${ }^{39}$ Tyndale, 'Towards Sustainable Development', 4.

${ }^{40}$ Marshall and Keough, Mind, Heart and Soul; K. Marshall and M. Van Saanen, Development and Faith: Where Heart, Mind and Soul Work Together (Washington, D.C.: The World Bank, 2007).

${ }^{41}$ See, amongst others, the following websites for shorter overview articles that deal with several of the abovementioned perspectives and nuances regarding the concept: www.hcsc.gc.ca/hppb/voluntarysector/bglossary.html; www.worldbank.org/prem/poverty/scapital/whatsc.htm.

${ }^{42}$ Cf. D. Bacon, 'Revitalizing Civil Society through Social Capital Formation in Faith-based Organizations: Reflections from Northern Ireland,' Social Development Issues 26/1 (2004): 14-24; E. Prins and D. M. Ewert, 'Cooperative Extension and Faith-based Organizations: Building Social Capital,' Journal of Extension 40, no. 3 (2002) [online] http://www.joe.org/joe/2002june/index.html; R.D. Putnam, 'Bowling Alone,' 65-78; G. Smith, 'Religion and the Rise of Social Capitalism: The Faith Communities in Community Development and Urban Regeneration in England,' Community Development Journal 37, no. 2 (2002): 167-177; E. Uslaner, Faith, Hope and Charity: Social Capital, Trust and Collective Action (College Park: Department of Government and Politics, University of Maryland, 1997); A. B. Yeung, 'An Intricate Triangle: Religiosity, Volunteering, and Social Capital: The European Perspective, the Case of Finland,' Nonprofit and Voluntary Sector Quarterly 33, no. 3 (2004): 401-422.

${ }^{43}$ Cf. M. Barnard, Liturgiek als Wetenschap van Christelijke Riten en Symbolen (Amsterdam: Vossiuspers, 2000); M. Barnard and P. Post (eds.), Ritueel Bestek: Antropologische Kernwoorden van de Liturgie (Zoetermeer: Meinema, 2001); C. Bell, 'Ritual Change and Changing Rituals,' Worship 63, no. 1 (1989): 31-41; C. Bell, Ritual Theory, Ritual Practice (New York/ Oxford: Oxford University Press, 1992); C. Bell, Ritual. Perspectives and Dimensions (Oxford: Oxford University Press, 1997); R. L. Grimes, Ritual Criticism: Case Studies in its Practice: Essays on its Theory (Columbia: University of South Carolina Press, 1990); R. L.
} 
well as the language of material symbols. ${ }^{44}$ Usually the concept is made operational by discerning various qualities of the concept. ${ }^{45}$ In our project qualities of ritual are used as they have notably been developed by African scholars and can be applied in an African context of poverty. In African interpretations of the concept, the quality 'transcendent/ mystical/ religious/ cosmic' ${ }^{46}$ seems to be a dominant one: 'the transcendental is actual and ... the sacred is ordinary in the African world'. ${ }^{47}$ Pecklers points to values that 'are embodied in our rituals'. ${ }^{48}$ Value formation and value reflection are important qualities of ritual with regard to our research on ritual and social capital formation. Time, space and people are furthermore investigated as important dimensions of ritual in the project. And in this regard we are particularly interested to explore how 'time' (which incorporates reference to the past, actual context and expectations of the future), as a dimension of ritual, reveal changes and developments that reflect certain transformations in South African society and in people's lives, and, in turn, how 'space' reveals similar changes because of migration and other social factors. As people express themselves in rituals and as they are at the same time shaped by rituals, ${ }^{49}$ 'people' performing rituals are considered the most important dimension in the project. Ritual both shapes a social reality performatively and is an expression of reality. It is performed according to a certain tradition and is at the same time 'reinvented' ${ }^{50}$ in accordance with the context. ${ }^{51}$ In short, ritual is product and producer of a particular social reality. This brings us to a next key concept.

\section{Dynamics of ritual and culture}

It has been generally accepted among scholars that there is a critical reciprocal interaction between ritual and culture through which a new entity comes into being, namely a reinvented and recontextualised ritual and - to a certain extent - a transformed culture. ${ }^{52}$ The exact nature of these dynamics is defined in the project in terms of our understanding of the abovementioned concepts. This implies that ritual activity interacts with the surrounding culture of poverty, and conversely that the culture of poverty interacts with the ritual activity.

Grimes, Deeply into the Bone: Re-inventing Rites of Passage (Berkeley/ Los Angeles/ London: University of California Press, 2000); G. Lukken, Rituals in Abundance; J. Lukwata, Integrated African Liturgy. Spearhead nos. 164-166 (Eldoret: AMACEA Gaba Publications, 2003); F.K. Lumbala, Celebrating Jesus Christ in Africa: Liturgy \& Inculturation (Maryknoll: Orbis Books, 1998); R. A. Rappaport, Ritual and Religion in the Making of Humanity. Cambridge Studies in Social and Cultural Anthropology (Cambridge: Cambridge University Press, 1999); E. E. Uzukwu, Worship as Body Language: Introduction to Christian Worship: An African Orientation (Collegeville: The Liturgical Press, 1997).

${ }^{44}$ Cf. Uzukwu, Worship as Body Language; Rappaport, Ritual and Religion in the Making of Humanity.

${ }^{45}$ Cf. Grimes, Ritual Criticism, 14.

${ }^{46}$ Cf. Grimes, Ritual Criticism, 14.

${ }^{47}$ Uzukwu, Worship as Body Language, 52.

${ }^{48}$ Pecklers, Worship, 163.

${ }^{49}$ Cf. Rappaport, Ritual and Religion in the Making of Humanity.

${ }^{50}$ Cf. Grimes, Deeply Into The Bone.

${ }^{51}$ See Bell, 'Ritual Change and Changing Rituals,' as well as Rappaport, Ritual and Religion in the Making of Humanity.

52 See among others D. S. Amalorpavadass, 'Theological Reflections on Inculturation,' Studia Liturgica 20 (1990): 36-54; M. Barnard, 'Dynamiek van Cultus en Cultuur,' in Ritueel Bestek: Antropologische Kernwoorden van de Liturgie (eds. M. Barnard and P. Post; Zoetermeer: Meinema, 2001); A. J. Chupungco, Cultural Adaptation of the Liturgy (New York: Paulist Press, 1982); B. J. De Klerk, 'Wisselwerking tussen Liturgie en Kultuur in die Suid-Afrikaanse Konteks - Enkele vertrekpunte,' Praktiese Teologie in Suid-Afrika 16, no. 2 (2001): 57-75; L. Van Tongeren, 'De Inculturatie van de Liturgie tot (Stil)stand Gebracht?,' Jaarboek voor Liturgie-onderzoek 12 (1996) 164-186; C. J. Wepener, From Fast to Feast: A Ritual-liturgical Exploration of Reconciliation in South African Cultural Contexts. Liturgia Condenda 19 (Leuven/ Paris/ Dudley, MA: Peeters, 2009), 36-42. 
With regard to our research question on the relation between ritual and social capital, the dynamics of ritual and culture stand at the core of the research. This connection raises many questions, for example, about the supposed meaninglessness and uselessness of ritual. ${ }^{53}$ How does the project avoid the trap of functionalism? We are, amongst others, addressing this complex of questions in a separate publication. ${ }^{54}$ Briefly, in the present research project we devote special attention to the performative quality of ritual 'in the making of humanity', ${ }^{55}$ without considering rituals as instrumental in this process.

The logic behind this approach is based on the assumption that a major contribution of religious communities is based on their potential for social capital formation and value formation through their rituals. Religious communities are thus not only regarded as valuable for social development because of the infrastructure they can provide, but also, and especially, because of the (potential) impact of their rituals on social development through the formation of values that contribute to and sustain social capital. Our underlying hypothesis is that the combination of these concepts will enable us to move beyond a reductionist view of poverty, development, ritual and the role of religion in social development.

\section{Epistemological and methodological framework}

In order to make the link between ritual and development more intelligible by means of a systematic research process, the ethnographic technique of participatory observation ${ }^{56}$ has been adopted to study ritual activities in the two distinct settings in South Africa identified for the research. This method enables us to understand the functioning of rituals by means of a process of ritual criticism, ${ }^{57}$ utilise insights from ritual theory ${ }^{58}$ in the two different environments, and enhance our insight into the contribution of rituals to social capital formation.

In the process of conducting the above-mentioned empirical work, data-collection methods applicable to the collection of rituals are employed, in which rituals are seen as enacted phenomena within their multiple contexts, and studied in an integrated manner ${ }^{59}$ making use of 'thick descriptions', focus group activities and visual media, etc. ${ }^{60}$ Secondly and simultaneously, the ways in which participants appropriate rituals, as well as how nonparticipants view the rituals, are established through interviews and focus group activities.

\footnotetext{
53 See in this regard F. Staal, 'The Meaninglessness of Ritual,' in Readings in Ritual Studies (ed. R. L. Grimes; Upper Saddle River, NJ: Prentice Hall, 1996), 483-494, as well as a recent opposing view by W. E. A. Van Beek, De Rite is Rond: Betekenis en Boodschap van het Ongewone (Tilburg: Universiteitsdrukkerij, 2007).

${ }^{54}$ M. Barnard and C.J. Wepener, 'Ritual and functionality,' is an article which the authors are currently completing within the framework of this research project.

${ }^{55}$ Cf. Rappaport, Ritual and Religion in the Making of Humanity.

56 See in this regard N. T. Ammerman et al., Studying Congregations: A New Handbook (Nashville, TN: Abingdon Press, 1998); R. L Grimes, Beginnings in Ritual Studies (Columbia: University of South Carolina Press, 1995); C. V. Johnson, 'Researching Ritual Practice,' Studia Liturgica 35, no. 2 (2005): 204-220; M. D. Stringer, 'Liturgy and Anthropology: The History of a Relationship,' Worship 63, no. 6 (1989): 503-521; M. D. Stringer, On the Perception of Worship (Birmingham: Birmingham University Press, 1999); C. J. Wepener, 'Researching Rituals: On the Use of Participatory Action Research in Liturgical Studies,' Praktiese Teologie in Suid-Afrika 20, no. 1 (2005): 109-127.

${ }^{57}$ Cf. M. Barnard, 'Dynamiek van Cultus en Cultuur', and especially Grimes, Ritual Criticism.

${ }^{58}$ Scholars whose work are of special importance for this project include, amongst others, Mary Douglas, Ronald Grimes, Gerard Lukken, Roy Rappaport, Victor Turner and especially African scholars such as John Lukwata, Kabasele Lumbala and Elochukwu Uzukwu.

${ }^{59}$ Cf. P. G. J. Post, 'Introduction and Application: Feast as a Key Concept in a Liturgical Studies Research Design,' in Christian Feast and Festival: The Dynamics of Western Liturgy and Culture (ed. P.G.J. Post et al.; Leuven/ Paris/ Sterling/Virginia: Peeters, 2001); P. G. J. Post et al., Disaster Ritual: Explorations of an Emerging Ritual Repertoire. Liturgia Condenda 15 (Leuven/ Paris/ Dudley, MA: Peeters, 2003), 46.

${ }^{60}$ See Johnson, 'Researching Ritual Practice’ and Wepener, 'Researching Rituals'.
} 
The ritual data are being collected in the two areas already mentioned: a settled rural community in KwaZulu-Natal, and a more urbanised community in the Western Cape.

As an overarching epistemology we make use of participatory action research (PAR). ${ }^{61}$ Participatory action research has been described as 'an alternative system of knowledge production, based on the subjects' involvement in decisions regarding the questions asked', and also as 'a research process where people involved in the situation being studied, are enabled (in partnership with researchers and other role-players) to become actively involved in collective efforts to address and solve their social problems' ${ }^{62}$ This methodological choice is based especially on the political implications and empowering possibilities underlying the PAR paradigm, by bringing subject and object together to collaborate within the process of knowledge production. ${ }^{63}$ This collaboration entails, among other things, that the people from the communities under study should be part of the research process from start to finish, a dimension which had in fact already occurred in the pre-proposal workshop referred to earlier in this article. Within the space of this workshop, representatives from the selected local communities participated actively in the formulation of the proposal and in preliminary choices regarding the location of the field work research. ${ }^{64}$

Empirical research being the heart of this study, we employ both an 'emic' and 'etic' approach representing the 'insiders' and the 'outsiders' perspective respectively. In conformity with this approach we aim at a good description of the ritual data, followed by an analysis of these data in terms of the key concepts discussed earlier in this article.

Besides making use of PAR, our research also strives to be fundamentally interdisciplinary in nature. The project as such brings (at least) three disciplines together to scrutinise the main research topics from four different angles. They are: religion and theology; ritual and liturgical studies; development studies with a specific focus on social development; and, related to the latter, the specialisation in religion and development referred to in the introductory section of this article. From the point of view of religion, we are studying faith communities as cultural and social orders that are formed by - and at the same time express themselves in - their rituals, specifically within a context of poverty. The disciplines of religious studies and practical theology are deemed indispensable for understanding the culture of religious communities. Along with this disciplinary focus, the field of ritual and liturgical studies has a history of studying rituals, also specifically in an ethnographic fashion within their natural context. Lastly, the fields of development studies and of religion and development assist us not only in understanding the religious and anthropological data within a developmental framework, but also in strengthening the nexus between religion and social development that we attempt to achieve in the project. Experts from these disciplines are especially needed to interpret and analyse the relevant literature and policy documents on social development and social capital.

\footnotetext{
${ }^{61}$ Cf. E. Babbie and J. Mouton, The Practice of Social Research (Cape Town: Oxford University Press, 2001), 58-68; H. J. Hendriks, Studying Congregations in Africa (Wellington: Lux Verbi.BM 2004), 215-221; H. Strydom, 'Participatory Action Research,' in Research at Grass Roots: For the Social Sciences and Human Service Professions (eds. A.S. De Vos et al.; Pretoria: Van Schaik, 2005); Wepener, 'Participation and Power,' 49-66.

${ }^{62}$ Hendriks, Studying Congregations in Africa, 217, 219.

${ }^{63}$ Cf. Wepener, 'Researching Rituals,' 115.

${ }^{64}$ People present and helping with the formulation of the research question and other aspects of the original proposal included: academics from the Netherlands (from the fields of theology, religion and social development), academics from different South African universities (from the fields of theology, religion, social development and economics), local parish priests and parishioners coming from KwaZulu-Natal and the Western Cape who are actively involved in attempts at poverty alleviation in local communities, as well as church facilitators who help congregations to participate in efforts to alleviate poverty.
} 


\section{Conclusion}

As indicated in the introduction, our research project is steered by the question how and to what extent religious ritual contributes to the formation of kinds of social capital that assist, or could assist, in the alleviation of poverty in South African communities. This article aimed to provide the scientific outlines of how we are trying to answer this question. With this main question in mind we are at present, and at least until the end of the project in 2011:

- Undertaking conceptual reflection on key developmental concepts as used in national and international policy documents and academic literature, notably including social development, social capital and poverty;

- Undertaking conceptual reflection on key religious concepts, notably including ritual and the dynamics of ritual and culture;

- Investigating religious rituals and their appropriation in particular rural and semiurban migrant communities;

- Seeking to enhance understanding of the role of ritual with regard to social development needs and social capital formation, and to facilitate the development of an inculturated ritual practice with regard to social capital formation for poverty alleviation and social development;

- Seeking - by means of a better understanding of the role of ritual/religion in social capital formation for poverty alleviation - to influence state policy regarding the role of religion in social development.

\section{BIBLIOGRAPHY}

Amalorpavadass, D. S. 'Theological Reflections on Inculturation.' Studia Liturgica 20 (1990): 36-54.

Ammerman, N. T. Congregation \& Community. New Brunswick/ New Jersey/ London: Rutgers University Press, 1997.

Ammerman, N. T., Carroll, J.W. Dudley, C.S. and W. McKinney, Studying Congregations: A New Handbook. Nashville, TN: Abingdon Press, 1998.

Anheier, H., Glasius, M. and M. Kaldor, eds. Global Civil Society 2004/5. London: Sage, 2004.

Babbie, E. and J. Mouton. The Practice of Social Research Cape Town: Oxford University Press, 2001.

Bacon, D. 'Revitalizing Civil Society through Social Capital Formation in Faith-based Organizations: Reflections from Northern Ireland.' Social Development Issues 26, no. 1 (2004): 14-24.

Barnard, M. Liturgiek als Wetenschap van Christelijke Riten en Symbolen. Amsterdam: Vossiuspers, 2000. 
Barnard, M. 'Dynamiek van Cultus en Cultuur.' Pages 47-62 in Ritueel Bestek: Antropologische Kernwoorden van de Liturgie. Edited by M. Barnard and P. Post. Zoetermeer: Meinema, 2001.

Barnard, M. and P. Post, eds. Ritueel Bestek: Antropologische Kernwoorden van de Liturgie. Zoetermeer: Meinema, 2001.

Bell, C. 'Ritual Change and Changing Rituals.' Worship 63, no. 1 (1989): 31-41.

Bell, C. Ritual Theory, Ritual Practice. New York/ Oxford: Oxford University Press, 1992.

Bell, C. Ritual: Perspectives and Dimensions. Oxford: Oxford University Press, 1997.

Brown, R. K. and R. E. Brown. 'Faith and Works: Church-Based Social Capital Resources and African American Political Activism.' Social Forces 82, no. 2 (2003): 617-641.

Cilliers, J. H. and C. J. Wepener. 'Ritual and the Generation of Social Capital in Contexts of Poverty: A South African Exploration.’ International Journal of Practical Theology 11, no. 1 (2007): 39-55.

De Klerk, B. J. 'Wisselwerking tussen Liturgie en Kultuur in die Suid-Afrikaanse Konteks Enkele Vertrekpunte.’ Practical Theology in South Africa 16, no. 2 (2001): 57-75.

Department of Social Services and Poverty Alleviation, Social Capital Formation Document. Prepared for Cabinet Legkotla, 9-10 February 2005.

Francis, P. 'Social Capital, Civil Society and Social Exclusion.' Pages 71-91 in Development Theory and Practice: Critical Perspectives. Edited by U. Kothari and M. Minogue. Basingstoke: Palgrave, 2002.

Grimes, R. L. Ritual Criticism: Case Studies in Its Practice: Essays on its Theory. Columbia: University of South Carolina Press, 1990.

Grimes, R. L. Beginnings in Ritual Studies: Revised Edition. Columbia: University of South Carolina Press, 1995.

Grimes, R. L. Deeply into the Bone: Re-Inventing Rites of Passage. Berkeley/ Los Angeles/ London: University of California Press, 2000.

Hendriks, H. J. Studying Congregations in Africa. Wellington: Lux Verbi, 2004.

Hendriks, H. J. 'Census 2001: Religion in South Africa with Denominational Trends 19112001.' Pages 27-85 in South African Christian Handbook 2005-2006. Cape Town: Christian Network, 2005.

Hendriks, H. J. and J. C. Erasmus. 'Religious Affiliation in South Africa Early in the New Millennium: Markinor's World Values Survey.' Journal of Theology for Southern Africa 117 (November 2003): 80-96. 
Hendriks, H. J., Erasmus, J. C. and G. G. Mans. 'Congregations as Providers of Social Service and HIV/AIDS Care.’ Dutch Reformed Theological Journal 45, no. 2 (2004 Supplementum): 380-402.

Human Sciences Research Council (HSRC). 'Broken Trust, a Wake-up Call for Major Institutions.’ Media briefs 2000 [online], http://www.hsrc.ac.za/Media_Release140.phtml.

Institute for Justice and Reconciliation (IJR). 'South Africa: Trust in Institutions Takes a Dive.' Business Day, 22 January 2008 [online] http://allafrica.com/stories/200801220202.html.

Johnson, C. V. 'Researching Ritual Practice.’ Studia Liturgica 35, no. 2 (2005): 204-220.

Koegelenberg, R. A. 'Social Development Partnerships between Religious Communities and the State: Perspectives from the National Religious Association for Social Development.' Journal of Theology for Southern Africa 110 (July 2001): 97-109.

Koopman, N. 'Publieke Teologie in Suid-Afrika Vandag: Die Verhaal van die Beyers Naudé Sentrum vir Publieke Teologie.' Ongepubliseerde referaat gelewer by die Universiteit van Stellenbosch Dosente Forum reeks, 18 Mei 2005.

Louw, L. and R. A. Koegelenberg. 'Building a New South Africa: The Building of a Caring, Democratic and Equitable Society through Partnerships between the State and the National Religious Leader's Forum (NRLF).' Position paper prepared for the NRLF meeting with former President Thabo Mbeki, 29-30 April 2003. A Perspective from the National Religious Association for Social Development (NRASD) [online] http://www.sarpn.org.za/documents/d0000557/P506_Social_Development.pdf.

Lukken, G. Rituals in Abundance: Critical Reflections on the Place, Form and Identity of Christian Ritual in Our Culture. Liturgia Condenda 17. Leuven/ Dudley, MA: Peeters, 2005.

Lukwata, J. Integrated African Liturgy. Spearhead Nos. 164-166. Eldoret: AMACEA Gaba Publications, 2003.

Lumbala, F. K. Celebrating Jesus Christ in Africa: Liturgy \& Inculturation. Maryknoll: Orbis Books, 1998.

Marshall, K. 'Development and Religion: A Different Lens on Development Debates.' Peabody Journal of Education 76, no. 3/4 (2001): 339-375.

Marshall, K. and Keough, L. Mind, Heart and Soul in the Fight against Poverty. Washington: World Bank, 2004.

Marshall, K. and M. Van Saanen. Development and Faith: Where Heart, Mind and Soul Work Together. Washington, D.C.: The World Bank, 2007.

Pecklers, K. Worship. New Century Theology. London/ New York: Continuum, 2003. 
Pieterse, H. J. C. 'Die Rol van Rituele en Simbole in die Identiteitsvorming van 'n Geloofsgemeenskap - 'n Gereformeerde Perspektief.' Skrif en Kerk 19, no. 2 (1998): 342-347.

Post, P. G. J. 'Introduction and Application: Feast as a Key Concept in a Liturgical Studies Research Design.' Pages 47-77 in Christian Feast and Festival: The Dynamics of Western Liturgy and Culture. Edited by P. Post, G. Rouwhorst, L. van Tongeren and A. Scheer. Leuven/ Paris/ Sterling/Virginia: Peeters, 2001.

Post, P. G. J., Grimes, R. L., Nugteren, A., Pettersson, P. and H. Zondag. Disaster Ritual: Explorations of an Emerging Ritual Repertoire. Liturgia Condenda 15. Leuven/ Paris/ Dudley, MA: Peeters, 2003.

Prins, E. and D. M. Ewert. 'Cooperative Extension and Faith-based Organizations: Building Social Capital.' Journal of Extension 40, no. 3 (2002) [online] http://www.joe.org/joe/2002june/index.html.

Putnam, R. 'Bowling Alone: America’s Declining Social Capital.' Journal of Democracy 6, no. 1 (1995): 65-78.

Rappaport, R. A. Ritual and Religion in the Making of Humanity. Cambridge Studies in Social and Cultural Anthropology. Cambridge: Cambridge University Press, 1999.

Smit, D. J. 'Lex Orandi, Lex Credendi, Lex (Con)vivendi: Oriënterende Inleiding tot Liturgie en Etiek.' Nederduitse Gereformeerde Teologiese Tydskrif 45, no. 3 \& 4 (2004): 887907.

Smith, G. 'Religion and the Rise of Social Capitalism: The Faith Communities in Community Development and Urban Regeneration in England.' Community Development Journal 37, no. 2 (2002): 167-177.

Staal, F. 'The Meaninglessness of Ritual.' Pages 483-494 in Readings in Ritual Studies. Edited by . R. L. Grimes; Upper Saddle River, NJ: Prentice Hall, 1996.

Stringer, M. D. 'Liturgy and Anthropology: The History of a Relationship.' Worship 63, no. 6 (1989): 503-521.

Stringer, M. D. On the Perception of Worship. Birmingham: Birmingham University Press, 1999.

Strydom, H. 'Participatory Action Research.' Pages 408-423 in Research at Grass Roots: For the Social Sciences and Human Service Professions. Edited by A. S. De Vos, H. Strydom, C. B. Fouche and C. S. L. Delport. Pretoria: Van Schaik, 2005.

Swart, I., Rocher, H., Erasmus, J. C. and S. Green. Religion and Social Development in PostApartheid South Africa: Perspectives for Critical Engagement. Stellenbosch: SUN Press, 2010 forthcoming.

Swart, I. 'Mobilising Faith-based Organisations for Social Development through a Participatory Action Research (PAR) Process.' Social Work/Maatskaplike Werk 41, no. 4 (2005): 323-336. 
Swart, I. 'Churches as a Stock of Social Capital for Promoting Social Capital in Western Cape Communities.' Journal of Religion in Africa 36, no. 3-4 (2006): 346-378.

Swart, I. 'Meeting the Challenge of Poverty and Exclusion: The Emerging Field of Development Research in South African Practical Theology.' International Journal of Practical Theology 12, no. 1 (2008): 104-149.

Swart, I. 'Market Economic Development, Local Economic Experience and the Christian Movement towards Alternatives in a South African City Region.' Pages 259-279 in From Our Side: Emerging Perspectives on Development and Ethics. Edited by S. de Gruchy, N. Koopman and S. Strijbos. Amsterdam: Rozenberg, 2008.

Ter Haar, G. and S. Ellis, 'The Role of Religion in Development: Towards a New Relationship between the European Union and Africa.' The European Journal of Development Research 18, no. 3 (2006): 351-67.

Tyndale, W. 'Faith and Economics in 'Development': A Bridge Across the Chasm?' Development in Practice 10, no. 1 (2000): 9-18.

Tyndale, W. 'Towards Sustainable Development: A Shift in Values.' Commentary International Movement for a Just World 1, no. 8 (August 2001): 1-4.

Uslaner, E. Faith, Hope and Charity: Social Capital, Trust and Collective Action. College Park: Department of Government and Politics, University of Maryland, 1997.

Uzukwu, E. E. Worship as Body Language: Introduction to Christian Worship: An African Orientation. Collegeville: The Liturgical Press, 1997.

Van Beek, W. E. A. De Rite is Rond: Betekenis en Boodschap van het Ongewone. Tilburg: Universiteitsdrukkerij, 2007.

Van Tongeren, L. 'De Inculturatie van de Liturgie tot (Stil)stand Gebracht?' Jaarboek voor Liturgie-Onderzoek 12 (1996): 164-186.

Van Wensveen, L. Transforming Development: Exploring Approaches to Development from Religious Perspectives. Utrecht: Knowledge Centre for Religion and Development, 2007.

Ver Beek, K. A., 'Spirituality: A Development Taboo.' Development in Practice 10, no. 1 (2000): 31-43.

Verhagen, K. 'Organized Religion: The Forgotten Dimension.' Pages 263-273 in Beyond Prince and Merchant: Citizen Participation and the Rise of Civil Society.' Edited by J. Burbidge. New York: Pact Publications, 1997.

Wepener, C. J. 'Researching Rituals: On the Use of Participatory Action Research in Liturgical Studies.' Praktiese Teologie in Suid-Afrika 20, no. 1 (2005): 109-127.

Wepener, C. J. 'Participation and Power: Opportunities for Method and Theory in Liturgical Research from a Changing (Dutch Reformed) South African Liturgical Landscape.' Jaarboek voor liturgie-onderzoek 22 (2006): 49-66. 
Wepener, C. J. 'Liturgy on the Edge of Tradition.' Practical Theology in South Africa 23, no. 2 (2008): 313-335.

Wepener, C. J. From Fast to Feast: A Ritual-liturgical Exploration of Reconciliation in South African Cultural Contexts. Liturgia Condenda 19. Leuven/ Paris/ Dudley, MA: Peeters, 2009.

Wepener, C. J. and Pauw, J. C. 'Terug na die Toekoms - oor die Samehang tussen Rituele Tyd en Identiteit.' Scriptura 85, no. 1 (2004): 110-122.

Wepener, C. J. and J. H. Cilliers, 'Research on Liturgy and the Generation of Social capital in Contexts of Poverty: A South African Exploration.' In Religion and Social Development In Post-Apartheid South Africa: Perspectives For Critical Engagement. Edited by I. Swart, H. Rocher, J. Erasmus and S. Green. Stellenbosch: SUN Press, 2010 forthcoming.

Yeung, A. B. 'An Intricate Triangle: Religiosity, Volunteering, and Social Capital: The European perspective, the case of Finland.' Nonprofit and Voluntary Sector Quarterly 33, no. 3 (2004): 401-422. 